\title{
A KOMPLEX VIZUÁLIS KÖRNYEZET KATEGORIZÁCIÓJÁNAK NEUROFIZIOLÓGIAI MECHANIZMUSAI
}

\author{
KÉRI SZABOLCS \\ Szegedi Tudományegyetem, Pszichiátriai Klinika, Szeged \\ E-mail: szkeri@phys.szote.u.-szeged.hu
}

\section{ANTAL ANDREA}

Szegedi Tudományegyetem, Élettani Intézet, Szeged

E-mail: aantal@phys.szote.u.-szeged.hu

\begin{abstract}
Az alábbi összefoglalásban a komplex vizuális környezet kategorizációját kísérő neurofiziológiai mechanizmusokat tekintjük át. Az alkalmazott feladat során a vizsgálati személyeknek rövid ideig számítógép segítségével bemutatott színes fényképek alapján kellett eldönteniük, hogy azok tartalmaztak-e állatokat vagy sem. A kategorizációs feladatban regisztrált kiváltott válaszok egy korai differenciál-komponenst mutattak (150-200 ms), amely a nemállat képekre negatívabb volt (dN1), elsősorban a frontális elvezetésekben. A dN1 nem volt jelen Parkinson-kóros betegek esetében, míg Alzheimer-demenciában továbbra is kimutatható volt. Feltételezésünk szerint a dN1 a cortico-striatalis információáramlást tükrözi, amely a kategóriaspecifikus vonások kiemelésének és integrációjának idegrendszeri alapja lehet.
\end{abstract}

Kulcsszavak: kategorizáció, természetes vizuális környezet, Parkinson-kór, Alzheimer-demencia, kiváltott válaszok

\section{ÉSZLELÉSTŐL A DÖNTÉSHOZATALIG: A KATEGORIZÁCIÓS FOLYAMATOK FELÉPÍTÉSE}

A mindennapi tevékenységek jelentős többsége kategorizációs folyamatokhoz kapcsolódik. Az állatvilágban a vizuális környezet gyors felbecsülése és a megfelelő viselkedési motívumok aktivációja túlélési értékű: a számos természetes komponens közül a ragadozó észlelése vagy az élelemforrás azonosítása például ellentétes 
viselkedést fog kiváltani. A humán tevékenység is gazdagon illusztrálható analóg helyzetekkel: az úttestre lépést megelőzően például gyors döntést kell hoznunk arról, hogy jön-e autó vagy sem. A percepciós folyamatok az utóbbi esetben a városi környezet analízisére korlátozódnak, a memóriaaktiváció pedig az autó képzetére koncentrálódik. A döntéshozatal e folyamat végeredményére épül. Látszólagos egyszerűsége ellenére a kategorizáció jelenségköre a megismerési folyamatok széles skáláját felöleli, az észleléstől a kivitelező funkciókig (SMITH, JONIDES, 2000). A fenti példánál maradva a természetes környezet feldolgozása rendkívül bonyolult folyamatokhoz kapcsolható, magában foglalva a formák és színek észleléséért felelős ventrális (occipito-temporális) és a mozgás/térbeli lokalizáció feldolgozását végző dorzális (occpitio-parietáis) kérgi területeket (VAN ESSEN, ANDERSON, FElleman, 1992; FARAH, Humphreys, Rodman, 1999). Az észlelés mindaddig nem vezet felismeréshez, amíg az aktuális információnak megfelelő belső reprezentáció nem aktiválódik. A környezet alkotóinak leképezése a szemantikus memória formájában a temporo-parietális területekre fókuszálódó neuronhálózat működéséhez rendelhető (DAmasio, H., Grabowski, Tranel, Hichwa, Damasio, A. R., 1996; BÜCHLER, PrICE, Friston, 1998). Végül e folyamatok magasabb szintủ koordinációjában, az információ döntéshozatalban és tervezésben történő felhasználásában (ún. kivitelező funkciók) a prefrontális területek játszanak központi szerepet (BADDELEY, 1992; SMITH, JONIDES, 1999). A fenti, leegyszerűsített vázlat jól mutatja, hogy a legtöbb bonyolultabb kognitív teszt során miért kell egy kiterjedt neuronhálózat aktiválódásával számolni, tekintettel arra, hogy a percepciós, memória és kivitelező funkciók egyaránt működésbe lépnek. Az elkövetkező összefoglalásban természetes, komplex vizuális ingerek kategorizációjának neurofiziológiai mechanizmusait tekintjük át, különös tekintettel néhány neuropszichiátriai kórképben történő alkalmazásra.

\section{TERMÉSZETES VIZUÁLIS INGEREK KATEGORIZÁCIÓJA: MÓDSZERTANI ÁTTEKINTÉS}

A kategorizációval foglalkozó vizsgálatok többsége leegyszerűsített ingereket használ, amelyek gyakran környezetükből kiragadott tárgyak fekete-fehér fényképei vagy rajzai. Hiányoznak tehát olyan vizuális vonások, amelyek a természetes környezetet jellemzik, beleértve a színeket, a felszíni mintázatokat, a térbeli frekvencia és a luminancia inhomogenitását és az egyes alkotók egymáshoz való viszonyát (RUDERMAN, 1997). A mesterséges tárgyakat alkalmazó módszerek a szemantikus szint aktiválódását is elkerülik. E megfontolásokból vizsgálatainkban természetes vizuális környezetről készült színes fényképeket használtunk, amelyek vagy tartalmaztak állatokat, vagy sem. Az állatok lehettek madarak, emlősök, hüllők, ízeltlábúak és tengeri élőlények. Az állatokat nem tartalmazó képek hasonló egyéb alkotókat vonultattak fel, beleértve hegyeket, erdőket, folyókat, tavakat, virágokat, gyümölcsöket, épületeket és városi környezetet emberekkel, járművekkel és más mesterséges tárgyakkal. Az ingerkészlet mintegy 3000 képből állt, amelyek számítógép segítségével identikus luminanciaviszonyok között kerültek bemutatásra, 
30 ms-os expozíciós idővel. A rövid bemutatási idő a kontrollált, nem párhuzamos percepciós folyamatok és a szemmozgások kiküszöbölését szolgálta. A vizsgálati személyek feladata egyszerű volt: eltérő gombok lenyomásával kellett jelezni, hogy az adott kép tartalmazott-e állatot (target) vagy sem (disztraktor). Alternatív lehetőség, hogy a résztvevőknek kizárólag az egyik esetben kell válaszolniuk, például egy folyamatosan nyomva tartott gomb felengedésével állatokat tartalmazó kép esetében (go/no go paradigma) (THORPE, FIZE, MARIOT, 1996).

A teljesítményen és a reakcióidőn kívül a kategorizációs folyamatot kísérő agyi elektromos aktivitást is nyomon követtük nyolc csatornán $(\mathrm{Oz}, \mathrm{Fz}, \mathrm{Cz}, \mathrm{Pz}, \mathrm{T} 3, \mathrm{~T} 4$, P3, P4) kiváltott válaszokat regisztrálva. A kiváltott válaszokat két módszerrel értékeltük. Egyrészt a célingerre és a disztraktorra nyert görbéket pontról pontra t-próbával hasonlítottuk össze. Amennyiben 15 egymást követő t-próba szignifikáns volt, a két görbe között különbség volt. A másik módszer szerint kiszámítottuk a görbe alatti területet (átlagos amplitúdó) az inger bemutatását követő 0-100, 150-250, 300-400 és 400-600 ms időintervallumokban (ANTAL, KÉRI, KOVÁCS, JANKA, BENEDEK, 2000).

\section{A TERMÉSZETES VIZUÁLIS INGEREK KATEGORIZÁCIÓJÁT KISÉRŐ, TÉRBEN ÉS IDŐBEN ELKÜLÖNÜLŐ FOLYAMATOK}

A vizsgálati személyek ( $\mathrm{n}=20$, átlagos életkor 29 év) meglepően jó teljesítményt nyújtottak. A 750 képnek több mint 95\%-át helyesen kategorizálták, a reakcióidő középértéke 533 ms volt. A négy időintervallumban a következő ERP komponenseket regisztráltuk (1.ábra) (ANTAL, KÉRI, KOVÁCS, JANKA, BENEDEK, 2000):

1. A 100-150 ms-os intervallumban egy pozitív komponens jelentkezett (P1), amely az állatokat tartalmazó és nem tartalmazó ingerekre hasonló amplitúdót mutatott, occipitális maximummal.

2. A 150-250 ms-os intervallumban egy negatív komponenst regisztráltunk (N1), amely az állatokat nem tartalmazó képek esetében negatívabb volt az állatokat tartalmaző képekhez viszonyítva. A t-próbák eredménye szerint a különbség legelőször az F3 elvezetésben jelentkezett, 162 ms-mal az inger bemutatását követően, majd 173 ms-nál minden elektródánál elérte a szignifikanciaszintet $(\mathrm{p}<0,05)$. Az átlagos amplitúdón elvégzett varianciaanalízis (ANOVA) és az azt követő post hoc tesztek Fz, Cz, F3 és F4 lokalizációban mutattak különbséget.

3. A 300-400 ms-os tartományba egy pozitív komponenst észleltünk (P2), amely az állatokat ábrázoló ingerek esetén pozitívabb volt az állatokat nem tartalmazó képekhez viszonyítva. A hatás minden elvezetésben megfigyelhető volt, de legelőször a Pz elektródának megfelelően jelentkezett.

4. A 400-600 ms-os tartományban ismét egy negatív hullám volt észlelhető (N2), amely az állatot nem ábrázoló fényképek esetén negatívabbnak bizonyult az állatokat tartalmazó képekhez viszonyítva, főképpen Pz lokalizációban. 
Az occipitális maximummal elvezethető első komponens (P1) megfelel a vizuális mintázatok által kiváltott primer válasznak (P100), amely az inger fizikai sajátságait tükrözi. Az N1 hullám, hasonlóképpen THORPE, FIZE és MARIOT (1996) eredményeihez, a disztraktor képek esetében negatívabb volt a target ingerekhez viszonyítva. Bár a különbség legkifejezettebben a frontális elvezetésekben mutatkozott meg, alig 10 ms-os késéssel a hátsó elektródáknak megfelelően is szignifikáns eltérés volt észlelhető. Ezzel szemben THORPE, FIzE és MARIOT (1996) kizárólag a frontális területeken észlelték a hatást. A különbség abból adódhat, hogy az eredeti paradigma go/no go jellegủ volt, míg esetünkben bináris döntést kellett hozni. A go/no go paradigma erősebb és aszimmetrikusabb gátlással jár, amely magyarázhatja a kifejezett frontális negativitás (PFEFFERbAUM, FORD, WELler, KOPPEL, 1985; GEMBA, SASAKI, 1989). A target és disztraktor esetében megegyező motoros tevékenységet igénylő bináris döntés viszont kizárja az állat-nemállat differenciálnegativitás $(\mathrm{dN} 1)$ gátlási és motoros eredetét, további bizonyítékot szolgáltatva arra, hogy a természetes vizuális környezet korai kategorizációjával öszszefüggő jelenségről van szó. Funkcionális mágneses rezonancia (fMRI) eljárást alkalmazó előzetes vizsgálatok szerint, némileg meglepő módon, a dN1 az occipitotemporális terület eltérő aktivitásához köthető, amely a komplex formafelismerésben vesz részt (Fize, Boulanouar, Ranjeva, Fabre-Thorpe, ThORPe, 1998). Valószínúbb azonban, hogy a gyors, kezdeti parallel vizuális analízis jele feedforward kapcsolatok révén eléri a prefrontális területeket, ahol a megfelelő viselkedési mintázat kiválasztása történik.

Distractors

a

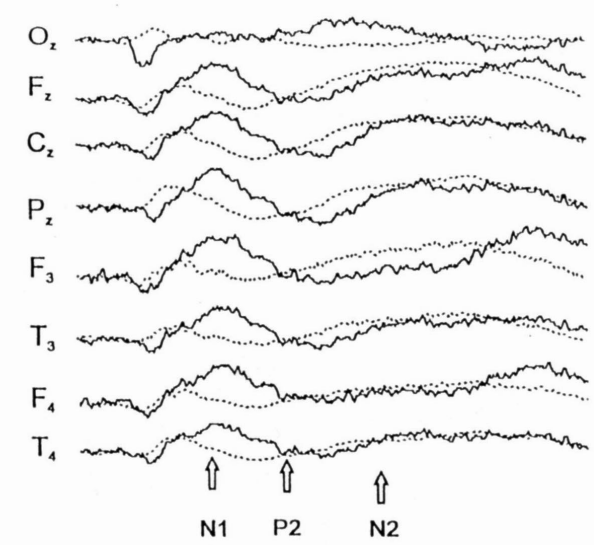

Targets

b

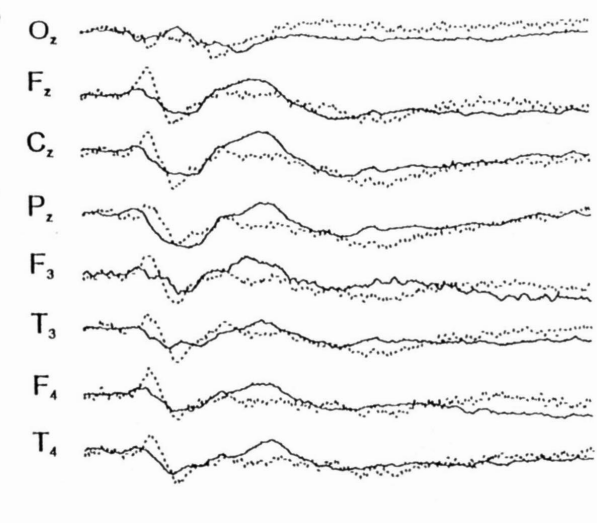

1. ábra. A target (állat) és disztraktor (nemállat) ingerekre kapott kiváltott válaszok

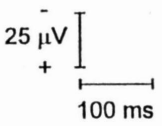

N1, P2, N2 komponensei. A folytonos vonal a kontrollszemélyek, a szaggatott vonal a Parkinson-kóros betegek eredményeit mutatja 
A temporo-frontális aktiváció automatikus jellegét tükrözi, hogy a figyelmi modulációval kapcsolatos késői pozitivitás (P2) a dN1-et követően jelentkezett, parietális maximummal. Ez a hullám, időbeli és topográfiai sajátságait tekintve, megfelel a P300 komponensnek. A P300 számos forrással rendelkezik a frontális, parietális és temporális kéreg területén és a figyelem célingerre történő transzlokációjával, a munkamemória tartalmának felfrissítésével állhat összefüggésben (Donchin, Ritter, McCallum, 1978; Halgren, Marinkovic, Chauvel, 1998). A feladat elején a vizsgálati személyeknek adott instrukciók szerint állatokat és minden egyéb mást tartalmazó képeket kell elkülöníteniük, vagyis a tudatos elvárás a homogénebb állatok kategóriájára összpontosul. Ez az információ a kontextust meghatározva tárolódik a munkamemóriában. Minden állatot bemutató kép a kontextusnak megfelelő, újabb kongruens bemeneti jelet biztosít. Ezzel ellentétesen a disztraktorok a kontextustól eltérően jelentkeztek, kisebb késői pozitivitást kiváltva.

Végül a P2-t követő késői negativitás (N2) a disztraktorok esetében nagyobb abszolút amplitúdót mutatott. Valószínű, hogy az N2 a szemantikus információfeldolgozással kapcsolatos N400 megfelelöje, amely a temporo-parietális területek felett vezethető el legnagyobb amplitúdóval. Számos vizsgálat tanulsága szerint az N400 a szemantikus kontextustól eltérő verbális vagy vizuális ingerek esetében negatívabb, hasonlóképpen jelen eredményeinkhez (KUTAS, VAN PETTEN, 1988; BARRETT, RUGG, 1990). Az N2 az osztályozott inger kategória-térben történő elhelyezkedését tükrözi. Amennyiben az inger tipikus képviselője a kategóriának (azaz az osztályozás szempontja által meghatározott kontextusba jól beleillik), az N2 pozitívabb, míg ellenkező, inkongruens helyzetben az N2 negatívabb (FUJIHARA, NAGEISHI, KOYAMA, NAKAJIMA, 1998).

Összefoglalva elmondható, hogy a természetes vizuális ingerek kategorizációját négy, térben és időben elkülöníthető folyamat kísérte. Az első (P1) alapvető szenzoros elemzést jelent az elsődleges látókéreg területén. E komponens tekintetében nem volt különbség a két kategóriába tartozó ingerek között. Az N1 gyors, párhuzamos és kategóriaspecifikus vizuális információfeldolgozási folyamatokkal áll kapcsolatban, feed-forward áramlást biztosítva a prefrontális kéreg felé. A P2 a kategorizáció figyelmi-munkamemória komponensével függ össze, míg az N2 a szemantikus szint mutatója.

\section{VIZUÁLIS KATEGORIZÁCIÓ NEUROPSZICHIÁTRIAI KÓRKÉPEKBEN}

A temporo-frontális feed-forward elörecsatolási mechanizmussal kapcsolatban egy fontos kérdés merül fel. Az összetett ingerek gyors és célorientált elemzéséhez szükséges, hogy egyes kulcsvonások súlyozottan és integráltan kerüljenek feldolgozásra. Nem szükséges például a képen látható virágok, fák, domborzati minták stb. részletes észlelése; elég néhány kategóriaspecifikus kulcsvonás kiemelése és egyesítése (például szem, toll, szőr, láb stb.), amelyek végeredményben a döntéshozatalhoz elegendő támpontot adnak (TVERSKY, 1977; GATI, TVERSKY, 1984). Példaként említhető az arcok vizuális elemzésével kapcsolatos eset. Arcok esetében 
az állat-nemállat dN1-hez hasonló korai, specifikus kiváltott válasz regisztrálható. Ez az arcspecifikus korai komponens megjelenik abban az esetben is, ha csupán a szemek vannak jelen, vagyis a kategorizációhoz szükséges kulcsvonás kiemelésre kerül a feladat szempontjából irreleváns részletek közül (haj, szájak, orr stb.) (Bentin, Allison, Puce, Perez, McCarthy, 1996). A következőkben bemutatott előzetes eredmények e mechanizmus idegrendszeri alapjaira tesznek utalást.

Kiindulási pontként azon anatómiai adatok szolgáltak, amelyek az inferiortemporális (IT) kéreg és a neostriátum között kapcsolatok jelenlétét írták le: a ventrális látórendszerhez tartozó IT idegsejtek a basalis ganglionok területén található neostriátum pálcikaszerű területeire konvergálnak (CHENG, SALEEM, TANAKA, 1997). E területek a többkomponensű vizuális elemzés integratív pontjai lehetnek, a kategorizáció idegrendszeri alapjainak kulcspontját jelentve. Feltételezhető ugyanis, hogy a viselkedés szempontjából fontos szenzoros jegyek e struktúrákra konvergálnak, kiemelődve az IT kéregben zajló multidimenzionális feldolgozásból. Végül a neostriátum intenzív kapcsolatban áll a prefrontális területekkel, ily módon subcorticalis hidat képezve az anterior és posterior kéreg között (Ashby, Alfonso-Reese, Turken, WALDron, 1998). A temporo-frontális kapcsolatok természetesen nem kizárólag kéreg alatti átkapcsolódással valósulhatnak meg: a két területet direkt cortico-corticalis pályák is összekötik (2. ábra). A kérdés nyitott: az N1 keletkezésében a kéreg alatti vagy a kérgi kapcsolatok játszanak-e döntő szerepet? A probléma megválaszolásához két neuropszichiátriai kórképet választottunk ki. Parkinson-kórban (PK) a neostriátum dopaminerg beidegzése

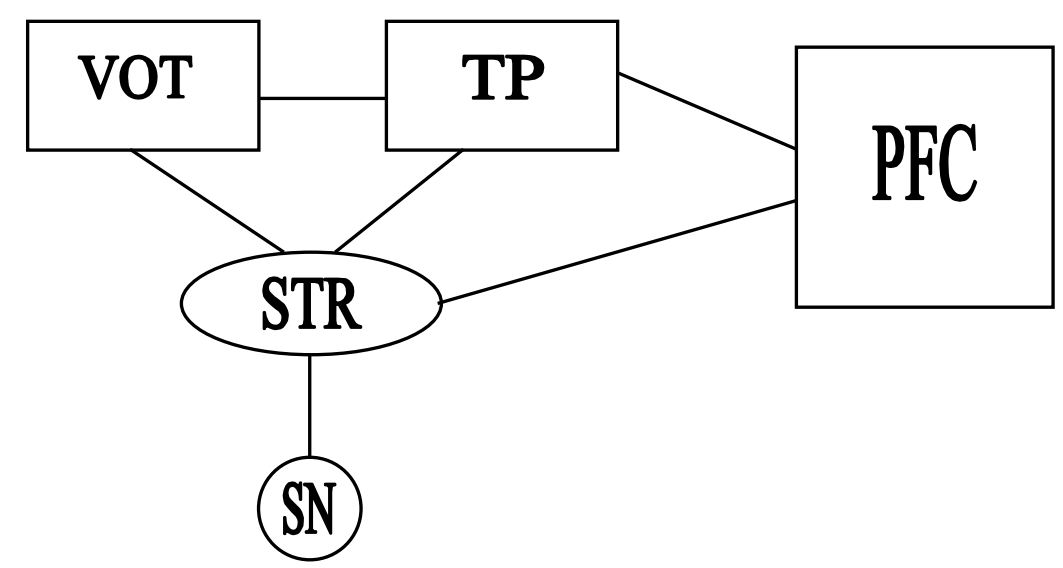

2. ábra. A vizuális kategorizációban részt vevő idegrendszeri struktúrák vázlata

Az ingerek perceptuális feldolgozása a ventrális occipito-temporális kéreghez (VOT) köthető, míg a szemantikus analízis a temporo-parietális (TP) területeken történik. A kategóriareleváns vonások kiemelése a kéreg és a neostriátum (STR) kölcsönhatása révén valósul meg, mely utóbbi kapcsolatban áll a prefrontális cortex-szel (PFC). A PFC felelős a megfelelő viselkedési mintázatok kiválasztásáért. Parkinson-kórban a STR substantia nigrából (SN) eredő dopaminerg beidegzése károsodik, míg Alzheimer-demeciában a VOT és TP területek degeneratív elváltozása az elsődleges. 
károsodik, amely a cortico-striato-corticalis információáramlás zavarát eredményezi (HoRnYKIEWICZ, KISH, 1987; ASHby, AlFONSO-REeSE, TURKEN, WALDRON, 1998; KROPOTOV, ETLINGER, 1999). Ezzel szemben Alzheimer-demenciában (AD) az agykérgi idegsejtek degenerációjának és pusztulásának következtében a hosszú cortico-corticalis pályák megszakadnak, kérgi diszkonnekciót idézve elő (Hof, Vogt, Bouras, Morrison, 1997; Leuchter, NeWTon, CoOK, Walter, ROSENBERG-THOMPSON, LACHENBRUCH, 1992). Az állat-nemállat kategorizációs feladatban a kontrollszemélyek ( $\mathrm{N}=20$, átlagos életkor: 64 év) 93\%-os, az AD-os betegek ( $\mathrm{N}=20$, átlagos életkor: 69 év) $88 \%$-os, a PK-os páciensek $(\mathrm{N}=20$, átlagos életkor: 68 év) pedig 90\%-os teljesítményt nyújtottak. A reakcióidők a következők voltak: kontroll: $600 \mathrm{~ms}$, AD: $639 \mathrm{~ms}$, PK: $667 \mathrm{~ms}$. Az AD-ban szenvedő betegek jellegzetes módon képtelenek voltak az ingerek döntő többségének felismerésére: csupán azt észlelték, hogy volt-e állat az adott képen, a konkrét nevet nem tudták megadni.

Az elvégzett ANOVA és post hoc analízis (Tukey's HSD teszt) meglepő eredményt mutatott. Az idősebb kontrollszemélyek esetében a dN1 következetesen megfigyelhető volt, legnagyobb mértékben a frontális és temporális elvezetésben. Ezzel ellentétben a PK-os betegek csoportjában a dN1 eltủnt: a target és disztraktor ingerek hasonló korai negativitást váltottak ki (1. ábra). A csoportok közötti összehasonlítások szerint a célingerek esetében nem volt különbség a kontrollok és a PK-os személyek között, míg a disztraktorok szignifikánsan kisebb N1et váltottak ki a betegcsoportban. Huntington-choreában (HC), amely szintén a basalis ganglionok betegségei közé tartozik, hasonló jelenséget tapasztaltunk. ADban, bár az átlagos amplitúdók kisebbek voltak, a dN1 jelen volt. Mindkét betegcsoportban az N1 komponens később jelentkezett, amely az információfeldolgozási folyamatok általános lassúságát mutatja. Végül a késői komponensek is eltérést mutattak: PK-ban a P2, AD-ban pedig mind a P2, mind az N2 kifejezetten károsodott volt (Iragui, Kutas, Salmon, 1996; Antal, Bandini, Kéri, BodisWOLLNER, 1998).

Előzetes eredményeink tehát a subcorticalis hipotézist támasztják alá. PK-ban az ingerek felismerése nem károsodott - erre utal a megtartott teljesítmény és a normális N1 átlagos amplitúdó. Más szavakkal az occipito-temporális rendszer viszonylagosan intakt módon dolgozta fel a komplex vizuális ingereket, fontos kompenzációs forrást jelentve. Ezzel szemben a neostriátum károsodása miatt a kategóriareleváns vonások kiemelése és súlyozása kevésbé történt meg: a dN1 hiányzott. Valószínủleg ebből adódott a döntés lassúsága, amely meghaladta az AD-ban tapasztaltakat. Az AD bizonyos értelemben ennek tükörképét mutatja: a csökkent áltagos N1 amplitúdó és a károsodott felismerés az occipito-temporális területek patológiájára utal (HOF, VOGT, BOURAS, MORRISON, 1997). Ezzel ellentétben a viszonylagosan magas kategorizációs teljesítmény és a $\mathrm{dN} 1$ a neostriatális szelekció megkíméltségét mutatta. Ezek az adatok a P2 és N2 eltéréseivel együtt a klasszikus corticalis-subcorticalis demencia osztályozást támasztják alá. Subcorticalis folyamatok (PK) esetén az információfeldolgozás sebessége, a munkamemória és a figyelmi moduláció elsődlegesen károsodik, míg a corticalis degeneráció (AD) a magasabb szintű perceptuális és szemantikus folyamatokat érinti. 


\section{A KATEGORIKUS REPREZENTÁCIÓ IDEGRENDSZERI ALAPJAI}

A fentiekben ismertetett eredmények a humán látórendszer kiemelkedő kapacitását mutatják: az inger bemutatását követő 150-200 ms-os tartományban kategóriaspecifikus válaszok $(\mathrm{dNl})$ vezethetők el komplex, természetes vizuális ingerek esetében. A differenciál-válasz legkifejezettebb mértékben a frontális és temporális területeknek megfelelően észlelhető. A dN1 a kategorizáció korai, perceptuális szintjét tükrözi, amely gyors temporo-frontális feed-forward mechanizmusok révén közvetlen hatást gyakorol a viselkedési mintázatok kiválasztására. A kontrollált figyelmi modulációt tükröző késői pozitivitás (P2 vagy P300) és a szemantikai feldolgozással kapcsolatos komponens (N2 vagy N400) időben később jelentkezik (Thorpe, Fize, MARiot, 1996; Fize, Boulanouar, RANJEva, FAbre-Thorpe, ThORPe, 1998; Hillyard, Teder-SälejÄrvi, Münte, 1998; ANTAL, Kéri, KoVÁCS, JANKA, BENEDEK, 2000). Kiemelendő, hogy előzetes eredményeink szerint a dN1 létrejöttében az intakt neostriatális működések fontosak, a kategóriaspecifikus vonások kiemelésének, integrálásának és frontális területek felé történő közvetítésének idegrendszeri alapjaként (KROPOTOV, ETLINGER, 1999). Ezzel szemben a természetes vizuális környezet részletes feldolgozása a ventrális occipitotemporális területeken történik (VAN ESSEN, ANDERSON, FELLEMAN, 1992; FARAH, HUMPHREYS, RODMAN, 1999).

Felmerül a kérdés: vajon a dN1 specifikus-e az állat-nemállat megkülönböztetésre? Ismeretes, hogy hasonló korai specifikus válaszok evolúciós szempontból fontos vagy túltanult ingerek esetén is megjelennek: ilyenek az arcok vagy a verbális szimbólumok (SCHENDAN, GANIS, KUTAS, 1998). A neuropszichológiai irodalom egyik kulcskérdése a kategóriaspecifikus deficit jelenléte, amit a legkülönbözőbb kategóriák esetében leírtak. E klasszikus eredmények arra utalnak, hogy az egyes szemantikus egységek az agy külön részeiben, modulárisan helyezkednek el, ám a legújabb megközelítések az éles és abszolút elkülönülések ellen szólnak (Warrington, Shallice, 1984; Damasio, 1990; Caramazza, Shelton, 1998). A természetes vizuális ingerek kategorizációjával foglalkozó néhány vizsgálat tanulsága szerint az egyes kategóriák (ez esetben állat-nemállat) a temporo-frontális rendszer differenciál-aktivitásához köthetők (THORPE, FIZE, MARIOT, 1996; FIZE, Boulanouar, Ranjeva, Fabre-Thorpe, Thorpe, 1998; Antal, Kéri, Kovács, JANKA, BENEDEK, 2000). Ez két folyamatot tükröz. Az első egy gyors perceptuális analízis, amelyből a corctico-striatális kapcsolatok révén a kategóriareleváns elemek kiemelésre kerülnek. Ez a neocortex kiterjedt károsodása esetében (AD) is viszonylagosan megtartott lehet, magas kategorizációs teljesítményt biztosítva. A második folyamat a felismeréssel, szemantikus osztályozással és nyelvi funkciókkal kapcsolatos, elsősorban a temporo-parietális területek működését tükrözve. A neostriátum károsodásával járó PK-ban és HC-ban ez bizonyos szempontból megkímélt, ám a korai vonáskiemelés zavart szenved. Ezzel szemben AD-ban a korai kategorizációs folyamat viszonylagosan megtartott, míg a késői, magasabb szintű vizuális és szemantikus analízis súlyosan károsodott (2. ábra). Erre utal, hogy bár az AD-ban szenvedő betegek osztályozási teljesítménye megközelítette a 90\%-ot, az 
ingereknek csupán elenyésző kisebbségét voltak képesek felismerni és konkrétan megnevezni (Huff, Corkin, Growdon, 1986; Welsh, Butters, Hughes, MOHS, Heyman, 1992).

Mennyire állnak összhangban ezekkel az adatokkal a fokális agyi károsodáson átesett betegek vizsgálatával és a funkcionális képalkotással nyert eredmények? Spitzer, KischKa, GÜCKel, Bellemann, KAMmer, Seyyedi, Weisbord, SCHWARTZ és BRIX (1998) állatok, bútorok, gyümölcsök és használati eszközök képeinek megnevezése során elkülöníthető aktivitási lókuszokat mutatott ki a fronto-temporális területeken. Más szerzők a cselekvési mintázatok által reprezentált használati eszközök felismeréskor és megnevezésekor a prefrontális és premotoros területeken találtak aktivitást, míg a vizuális forma alapján azonosítható állatok esetében mediális-occipitális és IT területeknél volt megfigyelhető fokozott regionális vérátáramlás (PERANI, CAPPA, BETTINARDI, BRESSI, GORNOTempini, Matarrese, Fazio, 1995; Martin, Wiggs, Ungerleider, HaXby, 1996). Jól ismert a fusiform „arc-régió” körül kialakult vita: egyes szerző arcokra szelektív régiót találtak a ventrális temporális részeken (gyrus fusifromis), míg mások ezt nem reprodukálták (KANWISHER, MCDERMOTT, CHUN, 1997; AGUIRRE, Singh, D’Esposito, 1999). H. Damasio, Grabowski, Tranel, Hichwa és A. R. DAMASIO (1996) szintén sok vitát kiváltott tanulmányukban a lexikai előhívás specificitását mutatták ki: emberek, állatok és tárgyak megnevezésének zavara a temporo-parietális cortex elkülöníthető részeinek károsodása esetén volt jelen. Az igen heterogén, ellentmondásoktól sem mentes adatok kritikai áttekintése során CARAMAZZA és SHELTON (1998) arra a következtetésre jutott, hogy az egyetlen valóságosan disszociálható pár az élő-élettelen kategóriáit foglalja magában. Az állat-nemállat differenciál-negativitás tükrében ez a hipotézis vonzónak tűnhet, ám a megerősítése elött mindenféleképpen meg kell vizsgálni, hogy a dN1 más kategóriák esetében nincs-e jelen.

Alternatív megközelítést kínálnak ISHAI, UNGERLEIDER, MARTIN, SCHOUTEN és HAXBY (1999) eredményei. A szerzők a ventrális temporális területeken kategóriadomináns aktivitást találtak arcok, székek és házak esetében. A komplex környezet alkotóinak térbeli viszonyai mediálisabban, a gyrus parahippocampalisnak megfelelően kerülnek kódolásra (EPSTEIN, KANwISHER, 1998). Fontos azonban, hogy az egyes kategóriáknak megfelelő területek átfedést mutattak, vagyis az elkülönülés nem volt abszolút. Valószínű, hogy az egyes objektumok egy folytonos hasonlósági térben kerülnek kódolásra; egy adott kérgi terület aktvitása bizonyos vonások dominanciájától vagy egy prototipikus diszpozíciótól való távolságától függ (BÜlThOFF, Edelman, TARR, 1995; ellenérvként lásd FODOR, LePORE, 1996). Ez jól magyarázhatja a körülírt agyi sérülésnél vagy a temporális lebeny degeneratív elváltozásai során ( $\mathrm{AD}$, szemantikus demencia) tapasztalható kategóriakiesések sajátosságait. AD-ban például egyszerü, perceptuális kategóriák esetében a prototipikus reprezentáció szelektíven károsodhat, amely egyetlen kategórián belül részben megtartott teljesítményhez vezethet. Az adott prototípus elvesztése a kategória-tér kitágulását idézheti elő, befolyásolva a teljesítményt más osztályba tartozó ingerek esetében is (KÉRI, KÁLMÁN, RAPCSAK, ANTAL, BENEDEK, JANKA, 1999). 
A dorzális és ventrális vizuális rendszer tanulmányozása során megszokhattuk, hogy a humán eredmények sejtszintű mechanizmusai állatkísérletek során kerülnek tisztázásra (LOGOTHETIS, SHeinberG, 1996). Mi a helyzet a vizuális kategorizációval? Annyi bizonyos, hogy a majmok az emberhez hasonlóan képesek komplex, természetes vizuális ingerek gyors kategorizációjára és bizonyos fokú absztrakciót is végeznek (FABRE-THORPE, RICHARD, THORPE, 1998; VOGELS, 1999a). Nem sikerült azonban olyan sejteket izolálni az IT kéregben, amelyek az absztrakció neuronális mechanizmusait egyértelmủen közvetítenék (VOGELS, 1999b). Mesterséges kategóriák elsajátítása a fronto-temporális kapcsolatok révén valósul meg, a neostriátum lehetséges szerepére pedig már tettünk utalást (CHENG, Saleem, Tanaka, 1997; Tomita, Ohbayashi, Nakahara, Hasegawa, Miyashita, 1999). Idegsebészeti műtétre váró betegek basalis ganglionjából elvezetett sejtpopuláció-aktivitások intenzívebbnek bizonyultak, amennyiben a vizsgálati személyek figyeltek az adott ingerre, illetve ha az inger szemantikai tartalommal volt felruházva. A sejtek latenciája meglepően rövid volt (kb. $100 \mathrm{~ms})$. Figyelemre méltó, hogy ezek a sejtek eltérő frekvenciájú akciós potenciálokat bocsátottak ki, ha a stimulus alakjára, orientációjára vagy luminanciájára kellett figyelni (KROPOTOV, Etlinger, Ponomarev, Trofimova, KuZnetsov, 1992; Kropotov, Etlinger, 1999). Az adatok tehát arra utalnak, hogy a basalis ganglionok valóban részt vehetnek a kategóriakulcsok kiemelésében és figyelmi modulációjában. Összességében a gyermekcipőben járó sejtszintű kísérletek szerint is a cortico-striato-frontális neuronhálózat szerepe kezd kirajzolódni, amely összhangban áll a humán neuropszichológiai eredményekkel (ASHBY, ALFONSO-REESE, TURKEN, WALDRON, 1998).

\section{IRODALOM}

Aguirre, G. K., Singh, R., D’Esposito, M. (1999) Stimulus inversion and the responses of face and object-sensitive cortical areas. Neuroreport, 10, 189-194.

Antal, A., Bandini, F., Kéri, S., Bodis-Wollner, I. (1998) Visuo-cognitive dysfunction in Parkinson's disease. Clinical Neuroscience, 5, 147-152.

Antal, A., Kéri, S., Kovács, G., Janka, Z., Benedek, G. (2000) Early and late components of visual categorization: an event-related potential study. Cognitive Brain Research, 9, $117-119$

Ashby, F. G., Alfonso-Reese, L. A., Turken, A. U., Waldron, E. M. (1998) A neuropsychological theory of multiple systems in category learning. Psychological Reviews, 105, 442-481.

BADDELEy, A. (1992) Working memory. Science, 255, 556-559.

Barrett, S. E., RugG, M. D. (1990) Event-related potential and semantic matching of pictures. Brain and Cognition, 14, 201-212.

Bentin, S., Allison, T., Puce, A., Perez, E., McCarthy, G. (1996) Elelctrophysiological studies of face perception in humans. Journal of Cognitive Neuroscience, 8, 551-565.

Büchler, C., Price, C., Friston, K. (1998) A multimodal language region in the ventral visual pathway. Nature, 394, 274-277. 
Bülthoff, H. H., Edelman, S., Tarr, M. J. (1995) How are three-dimensional objects represented in the brain? Cerebral Cortex, 5, 247-260.

Caramazza, A., Shelton, J. R. (1998) Domain-specific knowledge systems in the brain: the animate-inanimate distinction. Journal of Cognitive Neuroscience, 10, 1-34.

Cheng, K., Saleem, K. S., Tanaka, K. (1997) Organization of corticostriatal and corticoamygdalar projections arising from the anterior inferotemporal area TE of the macaque monkey. Journal of Neuroscience, 18, 7902-7925.

Damasio, A. R. (1990) Category-related recognition defects as a clue to the neural substrates of knowledge. Trends in Neurosciences, 13, 95-98.

Damasio, H., Grabowski, T. J., Tranel, D., Hichwa, R. D., Damasio, A. R. (1996) A neural basis of lexical retrieval. Nature, 380, 499-505.

Donchin, E., Ritter, W., McCallum, W. C. (1978) Cognitive psychophysiology: the endogenous components of the ERP. In Callaway, E., Tueting, P., Koslow, S. H. (eds) Event-Related Brain Potentials in Man. 61-78. Academic Press, New York

EPSTEIn, R., KANWISHER, N. (1998) A cortical representation of the local environment. Nature, 302, 598-601.

FAbre-Thorpe, M., Richard, G., Thorpe, S. J. (1998) Rapid categorization of natural images by rhesus monkeys. Neuroreport, 9, 303-308.

Farah, M., Humphreys, G. W., Rodman, H. R. (1999) Object and face recognition. In Zigmond, M. J., Bloom, F. E., Landis, S. C., Roberts, J. L., Squire, L. R. (eds) Fundamental Neuroscience. 1339-1361. Academic Press, New York

Fize, D., Boulanouar, K., Ranjeva, J. P., Fabre-Thorpe, M., Thorpe, S. J. (1998) Brain activity during rapid scene categorization: a study using fMRI. Journal of Cognitive Neuroscience (suppl.), 72. (Abstract)

FODOR, J., LEPORE, E. (1996) The red herring and the pet fish: why concepts can't be prototypes. Cognition, 58, 253-270.

Fujihara, N., Nageishi, Y., Koyama, S., NAKajima, Y. (1998) Electrophysiological evidence for the typicality effect of human cognitive categorization. International Journal of Psychophysiology, 29, 65-75.

Gati, I., TVersky, A. (1984) Weighting common and distinctive features in perceptual and conceptual judgements. Cognitive Psychology, 16, 341-370.

Gemba, H., SAsaki, K. (1989) Potential related to go/no go hand movement task with color discrimination in humans. Neuroscience Letters, 101, 263-268.

Halgren, E., Marinkovic, K., Chauvel, P. (1998) Generators of the late cognitive potentials in auditory and visual obdball task. Electroencephalography and Clinical Neurophysiology, 106, 156-164.

Hillyard, S. A., Teder-SÄlejÄrvi, W. A., Münte, T. F. (1998) Temporal dynamics of early perceptual processing. Current Opinion in Neurobiology, 8, 202-210.

Hof, P. R., Vogt, B. A., Bouras, C., Morrison, J. H. (1997) Atypical form of Alzheimer's disease with prominent cortical atrophy: a review of lesion distribution and circuit disconnection in cortical visual pathways. Vision Research, 37, 3609-3626.

Hornykiewicz, O., Kish, S. J. (1987) Biochemical pathophysiology of Parkinson's disease. Advances in Neurology, 45, 19-34.

Huff, F. J., Corkin, S., Growdon, J. H. (1986) Semantic impairment and anomia in Alzheimer's disease. Brain and Language, 28, 235-249. 
Iragui, V., Kutas, M., Salmon, D. P. (1996) Event-related brain potentials during semantic categorization in normal aging and senile dementia of the Alzheimer's type. Electroencephalography and Clinical Neurophysiology, 100, 392-406.

Ishai, A., Ungerleider, L. G., Martin, A., Schouten, J. L., Haxby, J. V. (1999) Distributed representation of objects in the human ventral visual pathway. Proceedings of the National Academy of Sciences of the USA, 96, 9379-9384.

Kanwisher, N., McDermott, J., Chun, M. M. (1997) The fusiform face area: a module in human extrastriate cortex specialized for face perception. Journal of Neuroscience, 17, 4302-4311.

Kéri, S., Kálmán, J., Rapcsak, S. Z., Antal, A., Benedek, G., Janka, Z. (1999) Classification learning in Alzheimer's disease. Brain, 122, 1063-1068.

Kropotov, J. D., Etlinger, S. C. (1999) Selection and actions in the basal gangliathalamocortical circuits: review and model. International Journal of Psychophysiology, 31, 197-217.

Kropotov, J. D., Etlinger, S. C., Ponomarev, V. A., Trofimova, L. G., Kuznetsov, M. A. (1992) Event-related neuronal responses in the human strio-pallido-thalamic system. 2. Cognitive functions. Electroencephalography and Clinical Neurophysiology, 84, 386-393.

Kutas, M., VAn Petten, C. (1988) Event related potential studies of language. In Ackles, P. K., Jennings, J. R., Coles, M. G. H. (eds) Advances in Psychophysiology. 128-143. JAI Press, Greenwich

Leuchter, A. F., Newton, T. F., Cook, J. A., Walter, D. O., Rosenberg-Thompson, S., Lachenbruch, P. A. (1992) Changes in brain functional connectivity in Alzheimer-type and multi-infarct dementia. Brain, 115, 1543-1561.

Logothetis, N. K., Sheinberg, D. L. (1996) Visual object recognition. Annual Review of Neuroscience, 19, 577-621.

Martin, A., Wiggs, C. L., Ungerleider, L. G., Haxby, J. V. (1996) Neural correlates of category-specific knowledge. Nature, 379, 649-652.

Perani, D., Cappa, S. F., Bettinardi, V., Bressi, S., Gorno-Tempini, M., Matarrese, M., FAzIO, F. (1995) Different neural systems for the recognition of animals and man-made tools. Neuroreport, 6, 1637-1641.

Pfefferbaum, A., Ford, J. M., Weller, B. J., Koppel, B. S. (1985) ERPs to response production and inhibition. Electroencephalography and Clinical Neurophysiology, 60, 423-434.

Ruderman, D. L. (1997) Origins of scaling in natural images. Vision Research, 37, 33853398.

Schendan, H. E., Ganis, G., Kutas, M. (1998) Neurophysiological evidence for visual perceptual categorization of words and faces within 150 ms. Psychophysiology, 35, 240351.

Smith, E. E., Jonides, J. (1999) Storage and executive processes in the frontal lobes. Science, 283, 1657-1661.

Smith, E. S., Jonides, J. (2000) The cognitive neuroscience of categorization. In Gazzaniga, M. S. (ed.) The New Cognitive Neurosciences. 1013-1022. The MIT Press, Cambridge

Spitzer, M., Kischka, U., Gückel, F., Bellemann, M. E., Kammer, T., Seyyedi, S., Weisbord, M., Schwartz, A., BRIX, G. (1998) Functional magnetic resonance imaging of category-specific cortical activation: evidence for semantic maps. Cognitive Brain Research, 6, 309-319. 
Thorpe, S., Fize, D., Mariot, C. (1996) Speed of processing in the human visual system. Nature, 381, 520-522.

Tomita, H., Ohbayashi, M., Nakahara, K., Hasegawa, I., Miyashita, Y. (1999) Topdown signal from prefrontal cortex in executive control of memory retrieval. Nature, 401, 699-703.

Tversky, A. (1977) Features of similarity. Psychological Reviews, 84, 327-352.

Van Essen, D. C., Anderson, C. H., Felleman, D. J. (1992) Information processing in the primate visual system: an integrated systems perspective. Science, 255, 419-423.

VOGELS, R. (1999a) Categorization of complex visual images by rhesus monkeys. Part 1 : behavioural study. European Journal of Neuroscience, 11, 1223-1238.

Vogels, R. (1999b) Categorization of complex visual images by rhesus monkeys. Part 2: single-cell study. European Journal of Neuroscience, 11, 1239-1255.

Warrington, E. K., Shallice, T. (1984) Category-specific semantic impairments. Brain, $107,829-854$.

Welsh, K. A., Butters, N., Hughes, J. P., Mohs, R. C., Heyman, A. (1992) Detection and staging of dementia in Alzheimer's disease: use of the neuropsychological measures developed for the Consortium to Establish a Registry for Alzheimer's disease. Archives of Neurology, 49, 448-452.

\title{
NEUROPHYSIOLOGICAL MECHANISMS OF NATURAL SCENE CATEGORIZATION
}

\author{
KÉRI, SZABOLCS-ANTAL, ANDREA
}

The aim of this review was to summarize the neurophysiological mechanisms of natural scene categorization. In the basic paradigm, subjects were asked to categorize photographs of natural scenes, deciding whether the image contained animals or not. Recording event-related potentials, we found an early differential-component (150-200 ms), which was more negative for non-animal scenes (dN1), and mainly appeared at the frontal electrodes. $d N 1$ was not present in patients with Parkinson's disease, whereas it was observable in subjects with Alzheimer-dementia. We suggest that dN1 is related to cortico-striatal information processing, which can be the neuronal basis of feature extraction and integration in categorization tasks.

Key words: categorization, natural scenes, Parkinson's disease, Alzheimer-dementia, event-related potentials 